\title{
Reaction intermediate species during the steam reforming of methanol over metal modified molybdenum carbide catalysts
}

\author{
$\mathrm{Ji} \mathrm{Cao}^{a, 1}$, Yufei Ma ${ }^{a, 1}$, Guoqing Guan ${ }^{a, b *}$, Xiaogang $\mathrm{Hao}^{c}$, Xuli Ma ${ }^{b, c}$, \\ Zhongde Wang ${ }^{c}$, Katsuki Kusakabe ${ }^{d}$, Abuliti Abudula ${ }^{a, b}$
}

${ }^{a}$ Graduate School of Science and Technology, Hirosaki University, 3 Bunkyo-cho, Hirosaki, Aomori 036-8561, Japan

${ }^{b}$ North Japan Research Institute for Sustainable Energy, Hirosaki University, 2-1-3 Matsubara, Aomori 030-0813, Japan

'Department of Chemical Engineering, Taiyuan University of Technology, Taiyuan 030024, China

${ }^{d}$ Department of Nanoscience, Sojo University, 4-22-1 Ikeda, Kumamoto 860-0082, Japan

Corresponding author: Tel.: +81-17-762-7756; fax: +81-17-735-5411.

E-mail: guan@hirosaki-u.ac.jp (G. Guan)

${ }^{1}$ These authors contributed equally to this work. 


\begin{abstract}
To understand steam reforming of methanol (SRM) reaction pathways over the surfaces of various metal-modified molybdenum carbides, the reaction intermediate species generated during the SRM reaction are investigated by using a temperature programmed surface reaction (TPSR) approach, in which a mass spectroscopy is applied to detect the produced species on-line. It is found that the reaction temperature affects the formation of different intermediate species over different catalysts. At the temperature lower than $180^{\circ} \mathrm{C}$, SRM reaction proceeds over $\mathrm{Cu}$ modified molybdenum carbide surface through formic acid $(\mathrm{HCOOH})$ intermediate pathway, but at the temperature over $180{ }^{\circ} \mathrm{C}$, the reactions over pure $\beta-\mathrm{Mo}_{2} \mathrm{C}, \mathrm{Ni}, \mathrm{Cu}$ and $\mathrm{Pt}$ modified molybdenum carbide surfaces proceed through methyl-formate $\left(\mathrm{HCOOCH}_{3}\right)$ intermediate pathway. It is expected that these findings can help us to understand the mechanism on SRM reaction over molybdenum carbide based catalysts.
\end{abstract}

Keywords: Steam reforming of methanol; Molybdenum carbide; Metal-modified molybdenum carbide; Reaction intermediate species; Mechanism. 


\section{Introduction}

Compared with gaseous hydrogen storage, on-board hydrogen production by reforming liquid hydrogen carriers will be more potential for future commercialization. Steam reforming of methanol (SRM) is considered as one of the most favorable chemical processes for on-board hydrogen production because: (i) methanol is in liquid state at ambient condition; (ii) it has high hydrogen-to-carbon ratio; (iii) the activation of methanol can occur at low temperatures $\left(200-400{ }^{\circ} \mathrm{C}\right)$; (iv) methanol is sulfur free and can be produced from biomass [1].

Various catalysts have been developed for the SRM [1-10]. Cu-based catalyst is widely used for SRM reaction due to its high activity and high selectivity at low temperature. However, this kind of catalyst is easy to be deactivated by thermal sintering [1-5]. Group 8-10 catalysts have also been developed for the SRM with high activity and stability, but their performances are generally affected by the support. Noble metals like Pt, Pd and Au supported oxides generally shows high activity, stability and selectivity [710], but their cost hinders their large scale applications. In our previous studies [11-14], metal-modified molybdenum carbide catalysts were prepared for low-temperature SRM reaction. It is found that the activation of methanol molecule can be promoted by the loading of metal (Fe, $\mathrm{Co}, \mathrm{Ni}, \mathrm{Cu}$ or $\mathrm{Pt}$ ) on the molybdenum carbide, and water molecule 
is mainly activated on molybdenum carbide surface itself. By adjusting the molar ratio of metal to carbide, the catalytic activity and stability can be tuned. Moreover, surface oxidation is usually the main reason for deactivation of carbide catalysts [11-25].

Three different reaction pathways for the SRM reaction over catalyst have been proposed in the literature [26-32]. The first one is the methanol decomposition to $\mathrm{H}_{2}$ and CO followed by water gas shift (WGS) reaction (Pathway I, CO intermediate); the second one is methanol dehydrogenation to methyl-formate, which then further decomposed to $\mathrm{H}_{2}$ and $\mathrm{CO}_{2}$ (Pathway II); and the third one is the methanol dehydrogenation to formaldehyde followed by decomposition to final products (Pathway III ). These three pathways are summarized as the followings.

Pathway I (CO intermediate):

$$
\begin{aligned}
& \mathrm{CH}_{3} \mathrm{OH} \rightarrow 2 \mathrm{H}_{2}+\mathrm{CO} \\
& \mathrm{CO}+\mathrm{H}_{2} \mathrm{O} \rightarrow \mathrm{H}_{2}+\mathrm{CO}_{2} \text { (WGS reaction) }
\end{aligned}
$$

Pathway II (Methyl formate intermediate):

$$
\begin{aligned}
& 2 \mathrm{CH}_{3} \mathrm{OH} \rightarrow \mathrm{HCOOCH}_{3}+2 \mathrm{H}_{2} \\
& \mathrm{HCOOCH}_{3}+2 \mathrm{H}_{2} \mathrm{O} \rightarrow \mathrm{CH}_{3} \mathrm{OH}+\mathrm{HCOOH} \\
& \mathrm{HCOOH} \rightarrow \mathrm{H}_{2}+\mathrm{CO}_{2}
\end{aligned}
$$

Pathway III (Formaldehyde intermediate): 


$$
\begin{aligned}
& \mathrm{CH}_{3} \mathrm{OH} \rightarrow \mathrm{HCHO}+\mathrm{H}_{2} \\
& \mathrm{HCHO}+\mathrm{H}_{2} \mathrm{O} \rightarrow \mathrm{HCOOH}+\mathrm{H}_{2} \\
& \mathrm{HCOOH} \rightarrow \mathrm{H}_{2}+\mathrm{CO}_{2}
\end{aligned}
$$

For the pathway I, CO is the primary product. Based on thermodynamic condition of WGS reaction, $\mathrm{CO}$ concentration should be at least equal to or higher than the $\mathrm{H}_{2} \mathrm{O}$ concentration. However, Santacesaria and Carra [26] studied the SRM reation over CuZn catalyts in a continuous strired-tank reactor (CSTR) using Langmuir-Hinshelwood model, and found that $\mathrm{CO}$ concentration was lower than the equilibrium concentration of WGS rection. Luo and Asthagiri [27] applied density functional theory (DFT) to study the SRM reaction on Co (001) and Co (111) surface and found that CO cannot be obtained from the direct decomposion of methanol, but from the decomposition of $\mathrm{CH}_{2} \mathrm{O}$ which is generated by methanol dehydrogenation. These results indicate that the pathway I is doubtful. For the pathway I, based on the diffuse reflectance infrared fourier transform (DRIFT) spectroscopic results, Frank et al. [28] found that methyl formate was the intermediate species in SRM reaction over $\mathrm{Cu}$-based catalysts. Furthermore, according to plane-wave density functional theory, Lin et al. [29] considered that the methy formate intermediate should be formed by a reaction between formaldehyde and methoxyl. Yi et al. [30] identified the pathway II occurring on the $\mathrm{Au} / \mathrm{CeO}_{2}$ surface via in-situ temperature 
program surface reaction (TPSR) approach. For the pathway III, Takezawa and Iwasa [31] found that formaldehyde ( $\mathrm{HCHO})$ is an important intermediate involved in the SRM reaction over $\mathrm{Cu}$ and group VIII $(\mathrm{Ni}, \mathrm{Rh}, \mathrm{Pd}$ and $\mathrm{Pt})$ metal based catalysts, where the HCHO intermediate was formed by dehydrogenation of methanol. This was also identified by other researchers [32,33], who found that $\mathrm{CH}_{3} \mathrm{OH}$ is first dehydrogenated to $\mathrm{HCHO}$ followed by a nucleophilic attack of $\mathrm{H}_{2} \mathrm{O}$ to form $\mathrm{HCOOH}$, which is further decomposed to $\mathrm{H}_{2}$ and $\mathrm{CO}_{2}$ on $\mathrm{Cu}-\mathrm{Zn}$ based catalysts. The calculation results based on density functional theory (DFT) also indicated that HCHO intermediate involves in the SRM reaction on $\mathrm{Cu}(111)$ and $\mathrm{Pd}$ (111) surface [34]. On $\mathrm{Cu}$ (111) surface, $\mathrm{HCHO}$ intermediate can be formed by dehydrogenation of methanol though the $\mathrm{O}-\mathrm{H}$ bond scission at first and then, $\mathrm{HCHO}$ tends to react with hydroxyl by the dissociation of $\mathrm{H}_{2} \mathrm{O}$ to form hydroxymethoxy, which is finally decomposed to $\mathrm{CO}_{2}$. In contrast, on $\mathrm{Pd}(111)$ surface, $\mathrm{HCHO}$ intermediate can be formed via the $\mathrm{C}-\mathrm{H}$ bond breaking at first and then, directly decomposed to $\mathrm{CO}$ and $\mathrm{H}_{2}$. All these results indicate that for different catalysts, the intermediate species formed on their surfaces seems to be different. To understand the reaction pathway of SRM over metal-modified molybdenum carbide, in this study, the reaction intermediate species generated were investigated by using the TPSR approach, in which a mass spectroscopy was applied to detect the products on-line. The obtained 
data were analyzed and discussed.

\section{Experimental}

\subsection{Catalysts preparation}

The catalysts were synthesized with the same procedure described in our previous studies [11-13]. In short, the molybdenum carbide $\left(\beta-\mathrm{Mo}_{2} \mathrm{C}\right)$ was synthesized by carburizing molybdenum oxide $\left(\mathrm{MoO}_{3}\right)$ using temperature programmed reduction (TPR) method with $20 \% \mathrm{CH}_{4} / \mathrm{H}_{2}$ mixture. Subsequently, the as-prepared fresh sample was passivated at room temperature using a $1 \% \mathrm{O}_{2} / \mathrm{Ar}$ gas mixture. For preparation of metal modified molybdenum oxide $\left(\mathrm{M}-\mathrm{MoO}_{\mathrm{x}}\right)(\mathrm{M}: \mathrm{Pt}, \mathrm{Cu}$, and Ni), Firstly, aqueous solutions of $\left(\mathrm{NH}_{4}\right)_{6} \mathrm{Mo}_{7} \mathrm{O}_{24} \cdot 4 \mathrm{H}_{2} \mathrm{O}$ respectively mixed with $\mathrm{H}_{2} \mathrm{PtCl}_{6} \cdot 6 \mathrm{H}_{2} \mathrm{O}, \mathrm{Cu}\left(\mathrm{NO}_{3}\right)_{2} \cdot 3 \mathrm{H}_{2} \mathrm{O}$, $\mathrm{Ni}\left(\mathrm{NO}_{3}\right)_{2} \cdot 6 \mathrm{H}_{2} \mathrm{O}$ under stirring for $4 \mathrm{~h}$ at first, and then the mixture solutions were continuously stirred at $80^{\circ} \mathrm{C}$ until dried. After continuously dried at $110^{\circ} \mathrm{C}$ overnight, the samples were calcined in air at $500{ }^{\circ} \mathrm{C}$ for $4 \mathrm{~h}$. The obtained $\mathrm{M}-\mathrm{MoO}_{\mathrm{x}}$ precursors were carburized using the same method as that for preparation of $\beta-\mathrm{Mo}_{2} \mathrm{C}$. It is found that Pt$\mathrm{Mox}_{\mathrm{x}} \mathrm{C}_{\mathrm{y}}$ with a Pt/Mo molar ratio of 1.6/90(Pt-Mox $\left.\mathrm{C}_{\mathrm{y}}(1.6)\right)$ [11], Ni-Moz $\mathrm{C}$ with a Ni/Mo molar ratio of 1.6/98.4 (Ni-Mo2 $\mathrm{C}(1.6))[11,12], \mathrm{Cu}-\mathrm{Mo}_{2} \mathrm{C}$ with a $\mathrm{Cu} / \mathrm{Mo}$ molar ratio of 10/90 (Cu- $\left.\mathrm{Mox}_{\mathrm{y}}(10)\right)$ [13] showed the highest activity and stability for each metal-

modified molybdenum oxide. In this study, these three kinds of catalysts were for TPSR.

\subsection{Temperature Programmed Surface Reaction (TPSR)}

$\mathrm{CH}_{3} \mathrm{OH}$-TPSR and $\mathrm{CH}_{3} \mathrm{OH}-\mathrm{H}_{2} \mathrm{O}$-TPSR were respectively investigated in a quartz 
micro-reactor with an inner diameter of $6 \mathrm{~mm} .100 \mathrm{mg}$ passivated molybdenum carbide based catalyst was loaded in the reactor. Prior to the reaction, the catalyst was pretreated with $15 \% \mathrm{CH}_{4} / \mathrm{H}_{2}$ at $590{ }^{\circ} \mathrm{C}$ for $2 \mathrm{~h}$ in order to reduce the surface oxide, and then the temperature was raised to $700{ }^{\circ} \mathrm{C}$ with a heating rate of $1{ }^{\circ} \mathrm{C} / \mathrm{min}$ under $\mathrm{Ar}$ flow $(50$ $\mathrm{cm}^{3} / \mathrm{min}$ ), and remained at $700{ }^{\circ} \mathrm{C}$ for $2 \mathrm{~h}$ in order to remove the adsorbents on the catalyst surface, and finally the temperature was decreased to room temperature under Ar flow. TPSR was performed in $13 \% \mathrm{CH}_{3} \mathrm{OH}-\mathrm{Ar}\left(50 \mathrm{~cm}^{3} / \mathrm{min}\right)$ or $13 \% \mathrm{CH}_{3} \mathrm{OH}-13 \% \mathrm{H}_{2} \mathrm{O}-\mathrm{Ar}(50$ $\mathrm{cm}^{3} / \mathrm{min}$ ) gas flow, in which the reaction temperature was increased from the room temperature (RT) to $700{ }^{\circ} \mathrm{C}$ with a heating rate of $5{ }^{\circ} \mathrm{C} / \mathrm{min}$. The signal intensities of $\mathrm{CO}_{2}$ (m/e=44), $\mathrm{CO}(\mathrm{m} / \mathrm{e}=28), \mathrm{CH}_{4}(\mathrm{~m} / \mathrm{e}=15), \mathrm{H}_{2}(\mathrm{~m} / \mathrm{e}=2), \mathrm{H}_{2} \mathrm{O}(\mathrm{m} / \mathrm{e}=18), \mathrm{CH}_{3} \mathrm{OH}(\mathrm{m} / \mathrm{e}=31)$, $\mathrm{HCOOH}(\mathrm{m} / \mathrm{e}=46)$ and $\mathrm{HCOOCH}_{3}(\mathrm{~m} / \mathrm{e}=60)$ were on-line monitored by mass spectroscopy (MS, BEL Mass, BEL Japan Inc.).

\section{Results and discussion}

\subsection{Methanol decomposition pathway over $\beta$-Mo2 $\mathrm{C}$ surface}

Fig. $1 \mathrm{CH}_{3} \mathrm{OH}-\mathrm{TPSR}$ profiles over $\beta-\mathrm{Mo}_{2} \mathrm{C}$ catalyst surface. 
As stated above, in this study, TPSR is used to study the interaction between the reactants and catalyst surface. As shown in Fig.1 (a), for $\mathrm{CH}_{3} \mathrm{OH}-\mathrm{TPSR}$ over $\beta-\mathrm{Mo}_{2} \mathrm{C}$ surface, one can see that the decomposition of $\mathrm{CH}_{3} \mathrm{OH}$ starts at $205{ }^{\circ} \mathrm{C}$, which is consistence with the result obtained in our previous study $[11,12]$. When the reaction temperature is increased to $420{ }^{\circ} \mathrm{C}$, the methanol signal increases. This might be due to the coke formation from methanol dissociation at high temperature. Meanwhile, from Fig.1 (b), one can see that small amounts of two intermediate species, formic acid ( $\mathrm{HCOOH})$ and methyl formate $\left(\mathrm{HCOOCH}_{3}\right)$, appear along with $\mathrm{H}_{2}, \mathrm{CH}_{4}, \mathrm{CO}_{2}$ and $\mathrm{CO}$. As reported by other researchers [28-32], for other kinds of catalysts, the surface of catalyst is always dominated by methoxy and formate groups, and methyl formate usually appears in the product spectrum at high methanol surplus. Moreover, the formed methyl formate can be further converted to formic acid $(\mathrm{HCOOH})$, which can finally decompose to $\mathrm{H}_{2}$ and $\mathrm{CO}_{2}$. In this study, the results also indicate that the decomposition of methanol over $\beta$ - $\mathrm{Mo}_{2} \mathrm{C}$ catalyst surface also follows the methyl-formate $\left(\mathrm{HCOOCH}_{3}\right)$ intermediate species pathway, i.e., pathway II as indicated in eqs. (3)- (5). Here, the formation of formic acid can be attributed to the conversion of dioxymethylene $\left(\mathrm{H}_{2} \mathrm{COO}\right)$ as following [30]: 
Meanwhile, the formation of $\mathrm{CO}_{2}$ and $\mathrm{CH}_{4}$ in the outlet might be due to $\mathrm{HCOOCH}_{3}$ decomposition, and another possibility is that $\mathrm{CH} 4$ may be derived from methanation, from the generated $\mathrm{CO}_{2}$ and $\mathrm{H}_{2}$ (eq. (11)):

$$
\begin{aligned}
& \mathrm{HCOOCH}_{3} \rightarrow \mathrm{CO}_{2}+\mathrm{CH}_{4} \\
& \mathrm{CO}_{2}+4 \mathrm{H}_{2} \rightarrow \mathrm{CH}_{4}+2 \mathrm{H}_{2} \mathrm{O}
\end{aligned}
$$

It should be noted that the temperature for $\mathrm{CO}$ formation is higher than that for other species. As such, $\mathrm{CO}$ may be also derived from the decomposition of $\mathrm{HCOOCH}_{3}$ (eq. (12)), but it will compete with the formation of $\mathrm{CO}_{2}$ and $\mathrm{CH}_{4}$ (eq. (10)). The other possible way for $\mathrm{CO}$ formation may be from the reverse water gas shift reaction (eq. (13)).

$$
\begin{aligned}
& \mathrm{HCOOCH}_{3} \rightarrow \mathrm{CO}+\mathrm{CH}_{3} \mathrm{OH} \\
& \mathrm{CO}_{2}+\mathrm{H}_{2} \rightarrow \mathrm{CO}+\mathrm{H}_{2} \mathrm{O}
\end{aligned}
$$

\subsection{SRM pathway over $\beta-M_{2} \mathrm{C}$ surface}

Fig.2 shows $\mathrm{CH}_{3} \mathrm{OH}-\mathrm{H}_{2} \mathrm{O}$-TPSR profiles over $\beta-\mathrm{Mo}_{2} \mathrm{C}$ catalyst surface. One can see that the reaction starts at $210^{\circ} \mathrm{C}$, and with the reaction temperature increased to $410{ }^{\circ} \mathrm{C}$, the signal of $\mathrm{H}_{2} \mathrm{O}$ decreases sharply while that of $\mathrm{H}_{2}$ increases, indicating that the $\beta-\mathrm{Mo}_{2} \mathrm{C}$ 
surface could be oxidized by water (eq. (14)) at high reaction temperatures $\left(>400^{\circ} \mathrm{C}\right)$.

$$
\mathrm{H}_{2} \mathrm{O}+\beta-\mathrm{Mo}_{2} \mathrm{C}^{*} \rightarrow\left(\mathrm{MoO}_{\mathrm{x}}\right)+\mathrm{CO}+\mathrm{H}_{2}
$$

Compared with Fig.1, one can find that the the intensity of $\mathrm{CO}$ signal decreases by the addition of $\mathrm{H}_{2} \mathrm{O}$. This is due to WGS reaction (eq. (2)) occurring in the $\mathrm{CH}_{3} \mathrm{OH}-\mathrm{H}_{2} \mathrm{O}$ system. On the other hand, based on Fig.2 (b), it is obvious that only trace of $\mathrm{HCOOCH}_{3}$ can be detected, but the intermediate species of $\mathrm{HCOOH}$ still remains relatively high. In contrast, as shown in Fig.1(b), methyl formate can be easily detected in the case without steam. As such, it can be concluded that $\mathrm{HCOOCH}_{3}$ can react with $\mathrm{H}_{2} \mathrm{O}$ to generate $\mathrm{HCOOH}$ (eq. (4)). Here, methyl formate should be also the intermediate of methanol decomposition on the surface of catalyst, which could further react with $\mathrm{H}_{2} \mathrm{O}$ in the reaction system. Therefore, for SRM reaction over $\beta-\mathrm{Mo}_{2} \mathrm{C}$ catalyst surface, methyl formate $\left(\mathrm{HCOOCH}_{3}\right)$ should be the intermediate species.

Fig. $2 \mathrm{CH}_{3} \mathrm{OH}-\mathrm{H}_{2} \mathrm{O}-\mathrm{TPSR}$ profiles over $\beta-\mathrm{Mo}_{2} \mathrm{C}$ catalyst surface.

\subsection{SRM reaction pathway over metal-modified molybdenum carbide surface}


Fig.3 $\mathrm{CH}_{3} \mathrm{OH}-\mathrm{TPSR}$ profiles over Ni-Mo2 $\mathrm{C}(1.6)$ catalyst surface.

Fig.4 $\mathrm{CH}_{3} \mathrm{OH}-\mathrm{H}_{2} \mathrm{O}-\mathrm{TPSR}$ profiles over Ni-Mo2 $\mathrm{C}$ (1.6) catalyst surface.

If compare Fig.3 with Fig. 1, one can find that the start temperature for the methanol decomposition is decreased by modification of $\mathrm{Ni}$ on the molybdenum carbide catalyst surface, indicating that the dissociative adsorption of methanol molecule is enhanced by the loaded Ni metal, which is generally considered to be benefit for the hydrocarbon reforming reaction. On the other hand, if compare Fig.4 with Fig.2, one can see that the SRM reaction also starts at lower temperature $\left(175^{\circ} \mathrm{C}\right)$ due to the modification of $\mathrm{Ni}$ on the molybdenum carbide catalyst surface. With the reaction temperature increased to high range $\left(>400^{\circ} \mathrm{C}\right)$, there is no obvious decrease of water signal (Fig.4 (a)). Also, correlated with $\beta$-Mo2 $\mathrm{C}$-TPSR results, it can be found that the intermediate species on $\mathrm{Ni}-\mathrm{Mo}{ }_{2} \mathrm{C}$ (1.6) catalyst surface is almost the same as that on pure $\beta-\mathrm{Mo}_{2} \mathrm{C}$ surface. Therefore, the SRM reaction pathway on $\mathrm{Ni}-\mathrm{Mo}_{2} \mathrm{C}(1.6)$ is similar to that on the pure $\beta-\mathrm{Mo}_{2} \mathrm{C}$ catalyst surface.

Fig.5 Schematic illustration of SRM reaction on catalyst surfaces ((A) and (B): $\beta-\mathrm{Mo}_{2} \mathrm{C}$ surface; (C) and (D): Ni-modified $\mathrm{Mo}_{2} \mathrm{C}$ surface) *: adsorbed species. 
Fig.6 Catalytic oxidation-reduction cycle over $\mathrm{Ni}-\mathrm{Mo}_{2} \mathrm{C}$ catalyst.

Based on our previous studies [11-14], the oxidation of $\mathrm{Mo}_{2} \mathrm{C}$ with oxygen species is originated from the dissociation of $\mathrm{H}_{2} \mathrm{O}$ on $\beta-\mathrm{Mo}_{2} \mathrm{C}$ or metal-modified molybdenum carbide catalysts, and as such, the surface reaction mechanism can be assumed as illustrated in Fig. 5. As shown in Fig.5 (A) and (B), the rates of water adsorption and activation over $\beta-\mathrm{Mo}_{2} \mathrm{C}$ catalyst surface are fast due to the reduced property of the molybdenum carbide surface. It should be noted that water serves as the oxide reactant here. In contrast, methanol is a relatively more reduced reactant and thus, the rates of methanol adsorption and dissociation should be much slower than water dissociation on the molybdenum carbide surface. However, the reaction pathway during SRM reaction is still ambiguous. As shown in Fig.5 (B), with the time on stream, the molybdenum carbide surface can be gradually oxidized by oxygen species from the dissociation of water molecule. Moreover, it should be noted that the surface oxygen species could hinder other reactant adsorption. However, when the metal such as $\mathrm{Ni}$ is loaded on the molybdenum carbide surface, Ni could accelerate the rate of methanol activation and dissociation and as a result, more reduced species i.e. $\mathrm{CO}^{*}$ could be produced from methanol and the surface oxygen species generated from water could be reduced by $\mathrm{CO}^{*}$ species, as shown 
in Fig.5 (C) and (D). In conclusions, the deactivation of $\beta-\mathrm{Mo}_{2} \mathrm{C}$ catalyst during SRM reaction is due to that the reaction rate of water activation is faster than methanol dissociation. As such, the oxidized Mo species cannot be reduced by methanol. When metal such as Ni is loaded on the molybdenum carbide surface with suitable amount, the balance of oxidation and reduction rates can be achieved and an oxidation-reduction cycle shown in Fig.6 could be established over it. That is why the activity and stability of molybdenum carbide are greatly promoted by doping some metals with proper amount.

Fig. $7 \mathrm{CH}_{3} \mathrm{OH}-\mathrm{TPSR}$ profiles over $\mathrm{Cu}-\mathrm{Mo}_{2} \mathrm{C}$ (10) catalyst surface.

Fig.8 $\mathrm{CH}_{3} \mathrm{OH}-\mathrm{H}_{2} \mathrm{O}-\mathrm{TPSR}$ profiles over $\mathrm{Cu}-\mathrm{Mo}_{2} \mathrm{C}$ (10) catalyst surface.

Figs. 7 and 8 shows $\mathrm{CH}_{3} \mathrm{OH}$-TPSR and $\mathrm{CH}_{3} \mathrm{OH}-\mathrm{H}_{2} \mathrm{O}$-TPSR profiles over $\mathrm{Cu}-\mathrm{Mo}_{2} \mathrm{C}$ (10) catalyst surface, respectively. One can see that the activation of methanol molecule over $\mathrm{Cu}$ modified molybdenum carbide catalyst starts at a temperature as low as $90{ }^{\circ} \mathrm{C}$. Compared with the pure $\beta-\mathrm{Mo}_{2} \mathrm{C}$ catalyst, the activation temperature is greatly decreased. This indicates that the dissociative adsorption of methanol molecule can be greatly enhanced by the modification of $\mathrm{Cu}$. Here, methanol molecule is considered to be mainly 
adsorbed on the $\mathrm{Cu}$ metal surface. On the other hand, as shown in Fig.7(b), one can find that the methanol dissociation on the $\mathrm{Cu}-\mathrm{Mo}_{\mathrm{x}} \mathrm{C}_{\mathrm{y}}(10)$ catalyst surface has two stages: one is at the reaction temperature range of $90-180{ }^{\circ} \mathrm{C}$; the other is the reaction temperature over $180{ }^{\circ} \mathrm{C}$. Especially, in the first stage, only $\mathrm{HCOOH}$ intermediate species appears, indicating that the activation of methanol molecule can be enhanced at lower temperature due to the modification of $\mathrm{Cu}$ species. Based on our previous study [13], the high activity and stability should be attributed to the formation of $\mathrm{Cu}^{\mathrm{I}}$ species on the catalyst surface, which was detected by XPS analysis and the Auger Cu LMM spectra.

Similar as shown in Fig. 4, the results in Fig.8 indicate that the water signal has no significant decrease. As mentioned above, the oxidation-reduction cycle shown in Fig.6 should be also existed on the $\mathrm{Cu}$ modified molybdenum carbide catalyst surface.

Fig.9 $\mathrm{CH}_{3} \mathrm{OH}-\mathrm{TPSR}$ profiles over Pt-Mo $\mathrm{C}$ (1.6) catalyst surface.

Fig.10 $\mathrm{CH}_{3} \mathrm{OH}-\mathrm{H}_{2} \mathrm{O}-\mathrm{TPSR}$ profiles over Pt-Mo $2 \mathrm{C}$ (1.6) catalyst surface.

Figs. 9 and 10 shows $\mathrm{CH}_{3} \mathrm{OH}-\mathrm{TPSR}$ and $\mathrm{CH}_{3} \mathrm{OH}-\mathrm{H}_{2} \mathrm{O}-\mathrm{TPSR}$ profiles over $\mathrm{Pt}-\mathrm{Mox}_{\mathrm{y}}$ (1.6) catalyst surface, respectively. It is obvious that the methanol activation temperature 
is decreased more $\left(50{ }^{\circ} \mathrm{C}\right)$. This indicates that the methanol molecule can be dissociated on Pt modified molybdenum carbide catalyst even at near the room temperature. Our previous study also showed that $\mathrm{Pt}-\mathrm{Mox}_{\mathrm{y}}(1.6)$ catalyst has high activity and stability for SRM reaction at low temperatures [14] and the results are consistence with those shown here. On the other hand, as shown in Fig.10 (a), the water signal also has no significant decrease. This also indicates that the resistance of oxidation of molybdenum carbide has been enhanced by the modification of Pt. Furthermore, one can see that for the SRM reaction over Pt modified molybdenum carbide catalyst, methyl formate $\left(\mathrm{HCOOCH}_{3}\right)$ is also the intermediate species.

\subsection{Reaction pathway}

Table 1 The main features of $\beta-\mathrm{Mo}_{2} \mathrm{C}, \mathrm{Ni}-\mathrm{Mo}_{2} \mathrm{C}(1.6), \mathrm{Cu}-\mathrm{Mo} 2 \mathrm{C}(10)$ and

$$
\mathrm{Pt}-\mathrm{Mo} 2 \mathrm{C}(1.6)
$$

The main features of above catalysts can be summarized in Table 1. It shows that the metal modified $\mathrm{Mo}_{2} \mathrm{C}$ catalysts have obviously improved when compared with the common $\beta-\mathrm{Mo}_{2} \mathrm{C}$ in catalytic activity and stability. Based on these TPSR results, one can conclude that the reaction pathway over molybdenum carbide and metal modified 
molybdenum carbide catalyst surface is the pathway II, i.e., though the methyl formate $\left(\mathrm{HCOOCH}_{3}\right)$ intermediate species route. However, the methanol dissociation on the $\mathrm{Cu}-$ $\mathrm{Mox}_{\mathrm{y}}(10)$ catalyst surface has two stages: one is at the reaction temperature range of $90-180{ }^{\circ} \mathrm{C}$; the other is the reaction temperature over $180{ }^{\circ} \mathrm{C}$. Therefore, the reaction pathway can be summarized in the following 2 figures:

(i) SRM reaction pathway (formic acid $(\mathrm{HCOOH})$ intermediate pathway) over $\mathrm{Cu}-\mathrm{Mox}_{\mathrm{x}} \mathrm{C}_{\mathrm{y}}$ (10) in the temperature range of $90-180{ }^{\circ} \mathrm{C}$ (Fig.11):

Fig.11 Schematic diagram of SRM reaction pathway over $\mathrm{Cu}-\mathrm{Mox}_{\mathrm{x}} \mathrm{C}_{\mathrm{y}}(10)$ catalyst surface $\left(90-180^{\circ} \mathrm{C}\right)$.

(ii) $\mathrm{SRM}$ reaction pathway(methyl formate $\left(\mathrm{HCOOCH}_{3}\right)$ intermediate pathway) over $\beta-\mathrm{Mo}_{2} \mathrm{C}, \mathrm{Ni}-\mathrm{Mo}_{2} \mathrm{C}(1.6), \mathrm{Pt}-\mathrm{Mox}_{\mathrm{x}} \mathrm{C}_{y}(1.6)$ and $\mathrm{Cu}-\mathrm{Mox}_{\mathrm{x}} \mathrm{C}_{y}(10)$ at a reaction temperature over $180^{\circ} \mathrm{C}$ (Fig.12)

Fig.12 Schematic diagram of SRM reaction pathway over $\beta$-Mo2 $\mathrm{C}, \mathrm{Ni}-\mathrm{Mo}{ }_{2} \mathrm{C}(1.6), \mathrm{Cu}-$ $\mathrm{Mox}_{\mathrm{y}}(10)$ and $\mathrm{Pt}-\mathrm{Mox}_{\mathrm{y}} \mathrm{C}_{\mathrm{y}}(1.6)$ catalyst surfaces $\left(>180^{\circ} \mathrm{C}\right)$. 


\section{Conclusions}

In this study, to understand the SRM reaction pathway over various metal-modified molybdenum carbide surfaces, reaction intermediate species generated during SRM reaction over the catalyst are investigated by using a temperature programmed surface reaction (TPSR) approach, in which a mass spectroscopy is applied to detect the products on-line. It is found that the reaction temperature affects the formation of different intermediate species over different catalysts. At the temperature lower than $180^{\circ} \mathrm{C}, \mathrm{SRM}$ reaction proceeds over $\mathrm{Cu}$ modified molybdenum carbide surface through formic acid $(\mathrm{HCOOH})$ intermediate pathway, but at the temperature over $180{ }^{\circ} \mathrm{C}$, the reactions over pure $\beta-\mathrm{Mo}_{2} \mathrm{C}, \mathrm{Ni}, \mathrm{Cu}$ and $\mathrm{Pt}$ modified molybdenum carbide surfaces proceed through methyl-formate $\left(\mathrm{HCOOCH}_{3}\right)$ intermediate pathway. It is expected that these findings can help us understanding the mechanism on SRM reaction over molybdenum carbide based catalysts.

\section{Acknowledgements}

This work is supported by Japan Science and Technology Agency (JST), Japan and Aomori City Government. 


\section{References}

[1] S. Sá, H. Silva, L. Brandão, J. M. Sousa, A. Mendes. Catalysts for methanol steam reforming-A review. Appl. Catal. B: Environ., 99 (2010) 43-57.

[2] J. Papavasiliou, G. Avgouropoulos, T. Ioannides. Effect of dopants on the performance of $\mathrm{CuO}-\mathrm{CeO}_{2}$ catalysts in methanol steam reforming. Appl. Catal. B: Environ., 69 (2007) 226-234.

[3] G. Huang, B. J. Liaw, C. J. Jhang, Y. Z. Chen. Steam reforming of methanol over $\mathrm{CuO} / \mathrm{ZnO} / \mathrm{CeO}_{2} / \mathrm{ZrO}_{2} / \mathrm{Al}_{2} \mathrm{O}_{3}$ catalysts. Appl. Catal. A: Gen., 358 (2009) 7-12.

[4] S. D. Jones, H. E. Hagelin-Weaver. Steam reforming of methanol over $\mathrm{CeO}_{2}$ - and $\mathrm{ZrO}_{2}$-promoted $\mathrm{Cu}-\mathrm{ZnO}$ catalysts supported on nanoparticle $\mathrm{Al}_{2} \mathrm{O}_{3}$. Appl. Catal. B: Environ., 90 (2009) 195-204.

[5] S. C. Yang, W. N. Su, S. D. Lin, J. Rick, B. J. Hwang. Preparation of highly dispersed catalytic $\mathrm{Cu}$ from rod-like $\mathrm{CuO}-\mathrm{CeO}_{2}$ mixed metal oxides: suitable for applications in high performance methanol steam reforming. Catal. Sci. Technol., 2 (2012) 807-812.

[6] C. Wang, M. Boucher, M. Yang, H. Saltsburg, M. Flytzani-Stephanopoulos. ZnOmodified zirconia as gold catalyst support for the low-temperature methanol steam 
reforming reaction. Appl. Catal. B: Environ., 154 (2014) 142-152.

[7] L. Yang, G. D. Lin, H. B. Zhang. Highly efficient Pd-ZnO catalyst doubly promoted by $\mathrm{CNTs}$ and $\mathrm{Sc}_{2} \mathrm{O}_{3}$ for methanol steam reforming. Appl. Catal. A: Gen., 455 (2013) 137144.

[8] A. Haghofer, K. Föttinger, F. Girgsdies, D. Teschner, A. Knop-Gericke, R. Schlögl, G. Rupprechter. In situ study of the formation and stability of supported $\mathrm{Pd}_{2} \mathrm{Ga}$ methanol steam reforming catalysts. J. Catal., 286 (2012) 13-21.

[9] N. Yi, R. Si, H. Saltsburg, M. Flytzani-Stephanopoulos. Steam reforming of methanol over ceria and gold-ceria nanoshapes. Appl. Catal. B: Environ., 95 (2010) 87-92.

[10] B. Halevi, E. J. Peterson, A. Roy, A. DeLariva, E. Jeroro, F. Gao, Y. Wang, J. M. Vohs, B. Kiefer, E. Kunkes, M. Havecker, M. Behrens, R. Schlogl, A. K. Datye. Catalytic reactivity of face centered cubic PdZn $\alpha$ for the steam reforming of methanol. J. Catal., 291 (2012) 44-54.

[11] Y. Ma, G. Guan, C. Shi, A. Zhu, X. Hao, Z. Wang, K.i Kusakabe, A. Abudula. Lowtemperature steam reforming of methanol to produce hydrogen over various metal-doped molybdenum carbide catalysts. Inter. J. Hydrogen Energy, 39(2014) 258-266.

[12] Y. Ma, G. Guan, P. Phanthong, X. Hao, W. Huang, A. Tsutsumi, K. Kusakabe, A. Abudula. Catalytic activity and stability of nickel modified molybdenum carbide catalysts for steam reforming of methanol. J. Phys. Chem. C, 118(2014) 9485-9496. 
[13] Y. Ma, G. Guan, X. Hao, Z. Zuo, W. Huang, P. Phanthong, K. Kusakabe, A. Abudula. Highly-efficient steam reforming of methanol over copper modified molybdenum carbide, RSC Adv. 4(2014)44175-44184.

[14] Y. Ma, G. Guan, P. Phanthong, X. Li, J. Cao, X. Hao, Z. Wang, A. Abudula. Steam reforming of methanol for hydrogen production over nanostructured wire-like molybdenum carbide catalyst, Inter. J. Hydrogen Energy, 39(2014)18803-18811.

[15] S. S. Y. Lin, W. J. Thomson, T. J. Hagensen, S. Y. Ha. Steam reforming of methanol using supported $\mathrm{Mo}_{2} \mathrm{C}$ catalysts. Appl. Catal. A: Gen., 318 (2007) 121-127.

[16] P. Liu, J.A. Rodriguez. Water-gas-shift reaction on molybdenum carbide surfaces:

Essential role of the oxycarbide. J. Phys. Chem. B, 110 (2006) 19418-19425.

[17] R. Barthos, F. Solymosi. Hydrogen production in the decomposition and steam reforming of methanol on $\mathrm{Mo}_{2} \mathrm{C} /$ carbon catalysts. J. Catal., 249 (2007) 289-299.

[18] J. Patt, D.J. Moon, C. Phillips, L. Thompson. Molybdenum carbide catalysts for water-gas shift. Catal. Lett., 65 (2000) 193-195.

[19] A. Széchenyi, F. Solymosi. Production of hydrogen in the decomposition of ethanol and methanol over unsupported $\mathrm{Mo}_{2} \mathrm{C}$ catalysts. J. Phys. Chem. C, 111 (2007) 9509-9515. [20] Á. Koós, R. Barthos, F. Solymosi. Reforming of methanol on a K-promoted Mo2C/Norit catalyst. J. Phys. Chem. C, 112 (2008) 2607-2612.

[21] M. Nagai, A.M. Zahidul, Y. Kunisaki, Y. Aoki. Water-gas shift reactions on potassium- and zirconium-promoted cobalt molybdenum carbide catalysts. Appl. Catal. A: Gen., 383 (2010) 58-65.

[22] M. Nagai, A.M. Zahidul, K. Matsuda. Nano-structured nickel-molybdenum carbide 
catalyst for low-temperature water-gas shift reaction. Appl. Catal. A: Gen., 313 (2006) 137-145.

[23] M. Nagai, K. Matsuda. Low-temperature water-gas shift reaction over cobaltmolybdenum carbide catalyst. J. Catal., 238 (2006) 489-496.

[24] C. Shi, A. Zhang, X. Li, S. Zhang, A. Zhu, Y. Ma, C. Au. Ni-modified Mo2C catalysts for methane dry reforming. Appl. Catal. A: Gen., 431 (2012) 164-170.

[25] A. Zhang, A. Zhu, B. Chen, S. Zhang, C. Au, C. Shi. In-situ synthesis of nickel modified molybdenum carbide catalyst for dry reforming of methane. Catal. Commun., $12(2011) 803-807$.

[26] E. Santacesaria, S. Carra. Kinetics of catalytic steam reforming of methanol in a CSTR reactor. Appl. Catal. B: Environ., 5 (1983) 345-358.

[27] W. Luo, A. Asthagiri. Density functional theory study of methanol steam reforming on $\mathrm{Co}(0001)$ and $\mathrm{Co}(111)$ surfaces. J. Phys. Chem. C, 118 (2014) 15274-15285.

[28] B. Frank, F. Jentoft, H. Soerijanto, J. Kröhnert, R. Schlögl, R. Schomäcker. Steam reforming of methanol over copper-containing catalysts: Influence of support material on microkinetics. J. Catal., 246 (2007) 177-192.

[29] S. Lin, D. Xie, H. Guo. First-principles study of the methyl formate pathway of methanol steam reforming on $\operatorname{PdZn}\left(\begin{array}{lll}1 & 1 & 1\end{array}\right)$ with comparison to $\mathrm{Cu}\left(\begin{array}{lll}1 & 1 & 1\end{array}\right)$. J. Mol. Catal. A: Chem. 356 (2012) 165-170.

[30] N. Yi, R. Si, H. Saltsburg, M. Flytzani-Stephanopoulos. Steam reforming of methanol over ceria and gold-ceria nanoshapes. Appl. Catal. B: Environ., 95 (2010) $87-$ 
92.

[31] N. Takezawa, N. Iwasa. Steam reforming and dehydrogenation of methanol: Difference in the catalytic functions of copper and group VIII metals. Catal. Today, 36 (1997) 45-56.

[32] J. P. Breen, J. R. Ross. Methanol reforming for fuel-cell applications: development of zirconia-containing Cu-Zn-Al catalysts. Catal. Today, 51 (1999) 521-533.

[33] T. Shishido, Y. Yamamoto, H. Morioka, K. Takehira. Production of hydrogen from methanol over $\mathrm{Cu} / \mathrm{ZnO}$ and $\mathrm{Cu} / \mathrm{ZnO} / \mathrm{Al}_{2} \mathrm{O}_{3}$ catalysts prepared by homogeneous precipitation: Steam reforming and oxidative steam reforming. J. Mol. Catal. A: Chem., 268 (2007) 185-194.

[34] X. K. Gu, W. X. Li. First-Principles Study on the Origin of the Different Selectivities for Methanol Steam Reforming on $\mathrm{Cu}(111)$ and $\mathrm{Pd}(111)$. J. Phys. Chem. C, 114 (2010) 21539-21547. 


\section{Figure captions}

Fig.1 $\mathrm{CH}_{3} \mathrm{OH}-\mathrm{TPSR}$ profiles over $\beta-\mathrm{Mo}_{2} \mathrm{C}$ catalyst surface.

Fig.2 $\mathrm{CH}_{3} \mathrm{OH}-\mathrm{H}_{2} \mathrm{O}-\mathrm{TPSR}$ profiles over $\beta-\mathrm{Mo}_{2} \mathrm{C}$ catalyst surface.

Fig.3 $\mathrm{CH}_{3} \mathrm{OH}$-TPSR profiles over Ni-Mo2 $\mathrm{C}$ (1.6) catalyst surface.

Fig.4 $\mathrm{CH}_{3} \mathrm{OH}-\mathrm{H}_{2} \mathrm{O}-\mathrm{TPSR}$ profiles over Ni-Mo2 $\mathrm{C}$ (1.6) catalyst surface.

Fig.5 Schematic illustration of SRM reaction on catalyst surfaces ((A) and (B): $\beta-\mathrm{Mo}_{2} \mathrm{C}$ surface; (C) and (D): Ni-modified $\mathrm{Mo}_{2} \mathrm{C}$ surface) *: adsorbed species.

Fig.6 Catalytic oxidation-reduction cycle over $\mathrm{Ni}-\mathrm{Mo}_{2} \mathrm{C}$ catalyst.

Fig.7 $\mathrm{CH}_{3} \mathrm{OH}-\mathrm{TPSR}$ profiles over $\mathrm{Cu}-\mathrm{Mo}_{2} \mathrm{C}(10)$ catalyst surface.

Fig.8 $\mathrm{CH}_{3} \mathrm{OH}-\mathrm{H}_{2} \mathrm{O}-\mathrm{TPSR}$ profiles over $\mathrm{Cu}-\mathrm{Mo}_{2} \mathrm{C}$ (10) catalyst surface.

Fig.9 $\mathrm{CH}_{3} \mathrm{OH}-\mathrm{TPSR}$ profiles over Pt-Mo2 $\mathrm{C}$ (1.6) catalyst surface.

Fig.10 $\mathrm{CH}_{3} \mathrm{OH}-\mathrm{H}_{2} \mathrm{O}-\mathrm{TPSR}$ profiles over Pt-Mo $\mathrm{Mo}_{2} \mathrm{C}(1.6)$ catalyst surface.

Fig.11 Schematic diagram of SRM reaction pathway over $\mathrm{Cu}-\mathrm{Mo}_{\mathrm{x}} \mathrm{C}_{\mathrm{y}}(10)$ catalyst surface $\left(90-180^{\circ} \mathrm{C}\right) . \mathrm{c}$

Fig.12. Schematic diagram of SRM reaction pathway over $\beta-\mathrm{Mo}_{2} \mathrm{C}, \mathrm{Ni}-\mathrm{Mo}_{2} \mathrm{C}(1.6), \mathrm{Cu}-$ $\mathrm{Mox}_{\mathrm{y}}(10)$ and Pt-Mox $\mathrm{C}_{\mathrm{y}}(1.6)$ catalyst surfaces $\left(>180^{\circ} \mathrm{C}\right)$. 


\section{Table caption}

Table 1 The main features of $\beta-\mathrm{Mo}_{2} \mathrm{C}, \mathrm{Ni}-\mathrm{Mo}_{2} \mathrm{C}(1.6), \mathrm{Cu}-\mathrm{Mo}{ }_{2} \mathrm{C}(10)$ and $\mathrm{Pt}-\mathrm{Mo} 2 \mathrm{C}(1.6)$ 
Table 1

\begin{tabular}{|c|c|c|c|c|}
\hline & $\beta-\mathrm{Mo}_{2} \mathrm{C}$ & $\begin{array}{c}\mathrm{Ni}-\mathrm{Mo}_{2} \mathrm{C} \\
\quad(1.6)\end{array}$ & $\begin{array}{c}\mathrm{Cu}-\mathrm{Mo}_{2} \mathrm{C} \\
(\mathbf{1 0})\end{array}$ & $\begin{array}{c}\mathrm{Pt}-\mathrm{Mo}_{2} \mathrm{C} \\
(\mathbf{1 . 6 )}\end{array}$ \\
\hline Metal oxidation states & & $\mathrm{Ni}^{0^{*}}$ & $\mathrm{Cu}^{0^{*}}$ & $\mathrm{Pt}^{0^{*}}$ \\
\hline $\mathrm{CH}_{3} \mathrm{OH}$ conversion $\left(200^{\circ} \mathrm{C}\right)^{* *}$ & $3 \%$ & $17 \%$ & $64 \%$ & $99 \%$ \\
\hline Stability (h) & 9 & 12 & 11 & 50 \\
\hline $\begin{array}{c}\mathrm{CH}_{3} \mathrm{OH} \text { - TPSR reaction start } \\
\text { temperature }\left({ }^{\circ} \mathrm{C}\right)\end{array}$ & 205 & 175 & 90 & 120 \\
\hline $\begin{array}{c}\mathrm{CH}_{3} \mathrm{OH}-\mathrm{H}_{2} \mathrm{O} \text {-TPSR reaction } \\
\text { start temperature }\left({ }^{\circ} \mathrm{C}\right)\end{array}$ & 210 & 175 & 180 & 150 \\
\hline Reaction intermediates & $\begin{array}{c}\text { Formic } \\
\text { acid and } \\
\text { methyl } \\
\text { formate }\end{array}$ & $\begin{array}{c}\text { Formic acid } \\
\text { and methyl } \\
\text { formate }\end{array}$ & $\begin{array}{l}\text { Methyl } \\
\text { formate }\end{array}$ & $\begin{array}{l}\text { Methyl } \\
\text { formate }\end{array}$ \\
\hline
\end{tabular}

* Before test the catalysts were regenerated under $15 \% \mathrm{CH}_{4} / \mathrm{H}_{2}$ gas flow.

** References [11-13]. 
Fig.1
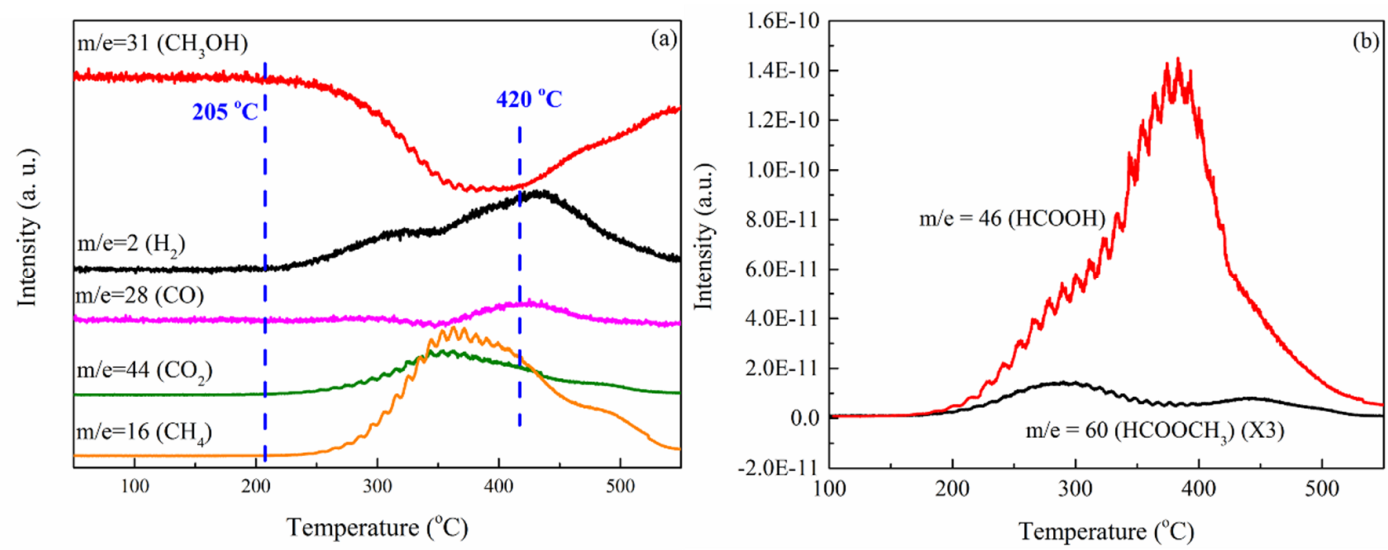
Fig.2
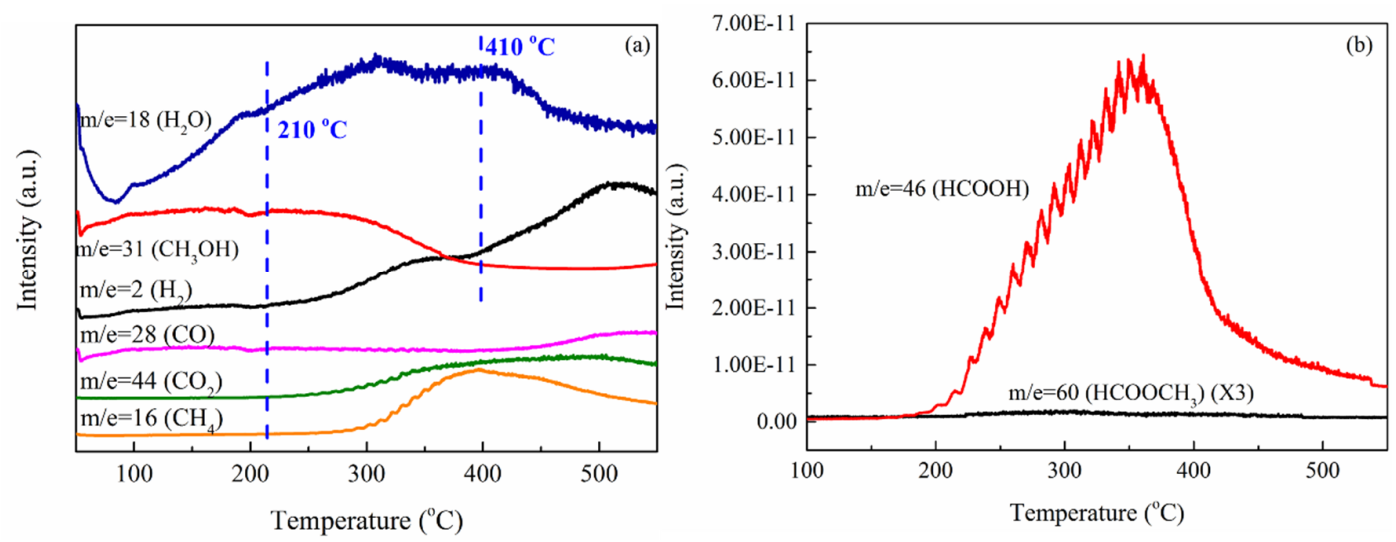
Fig.3
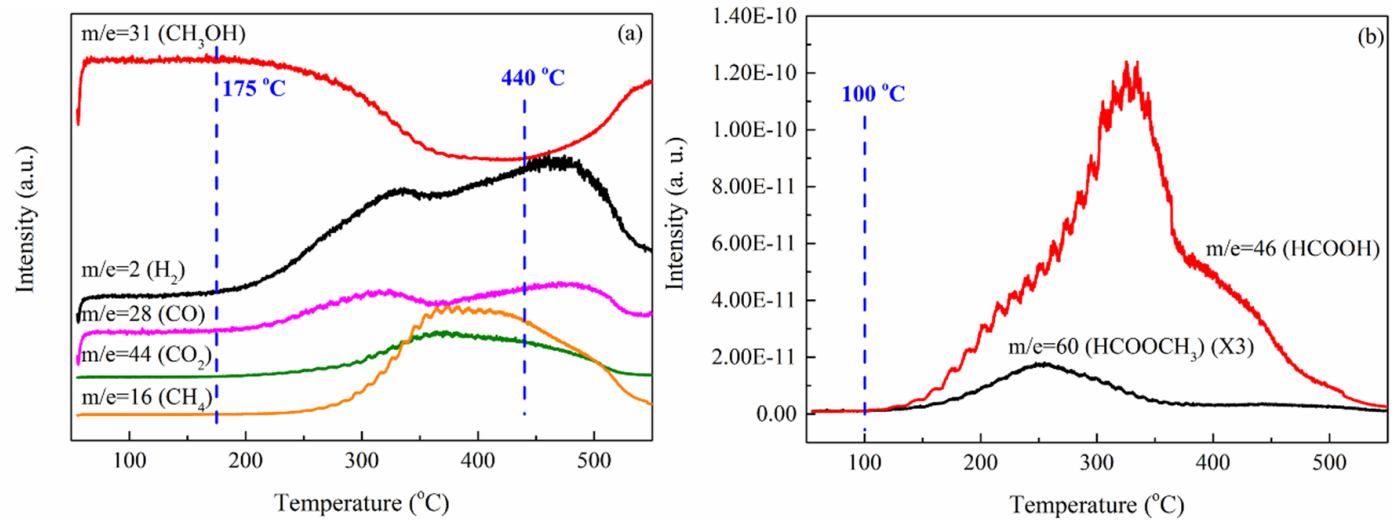
Fig.4
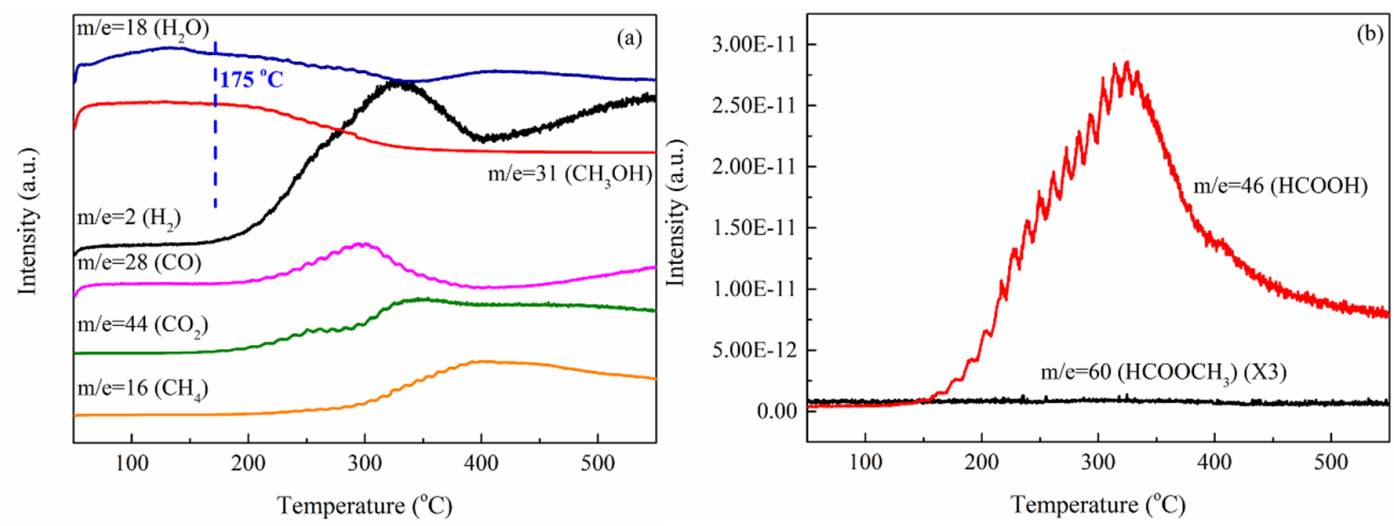
Fig.5

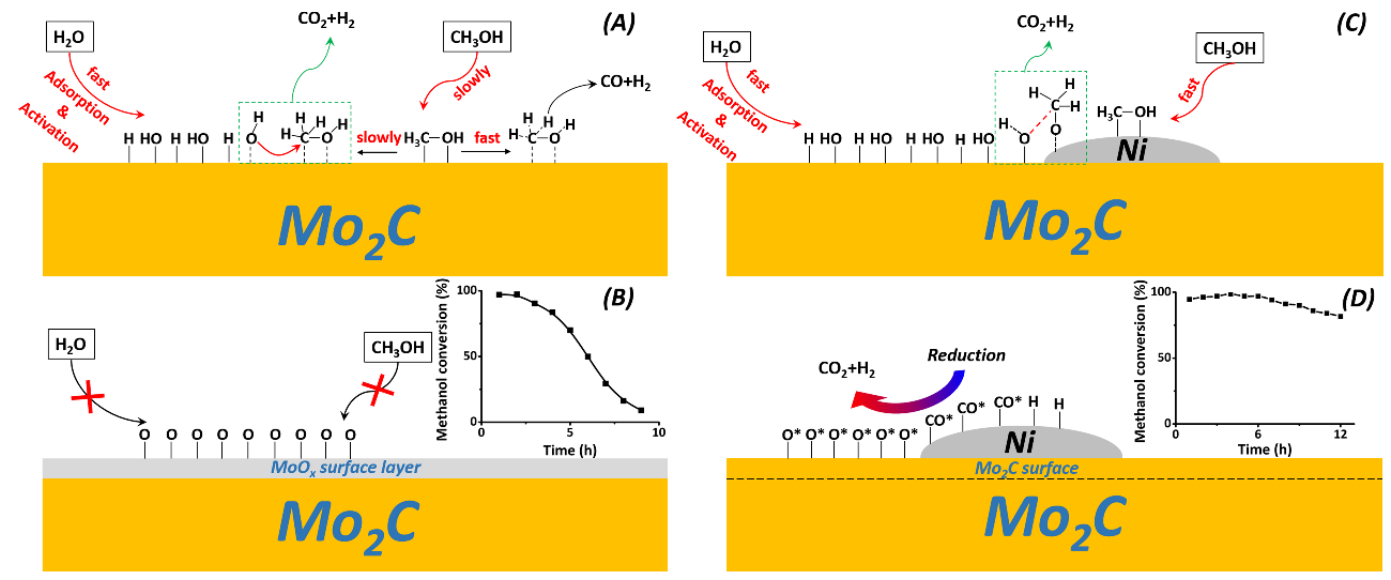


Fig.6

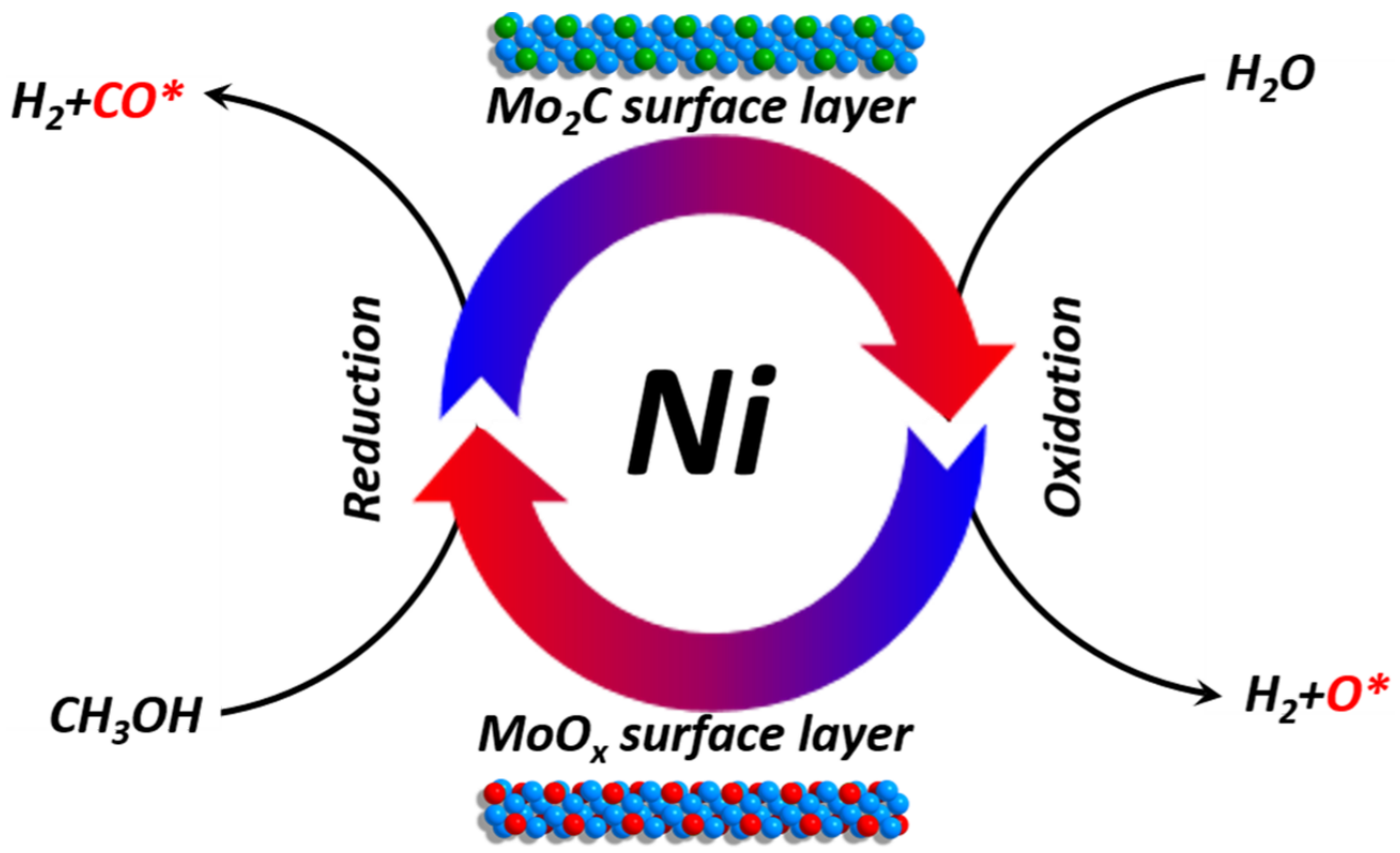


Fig.7
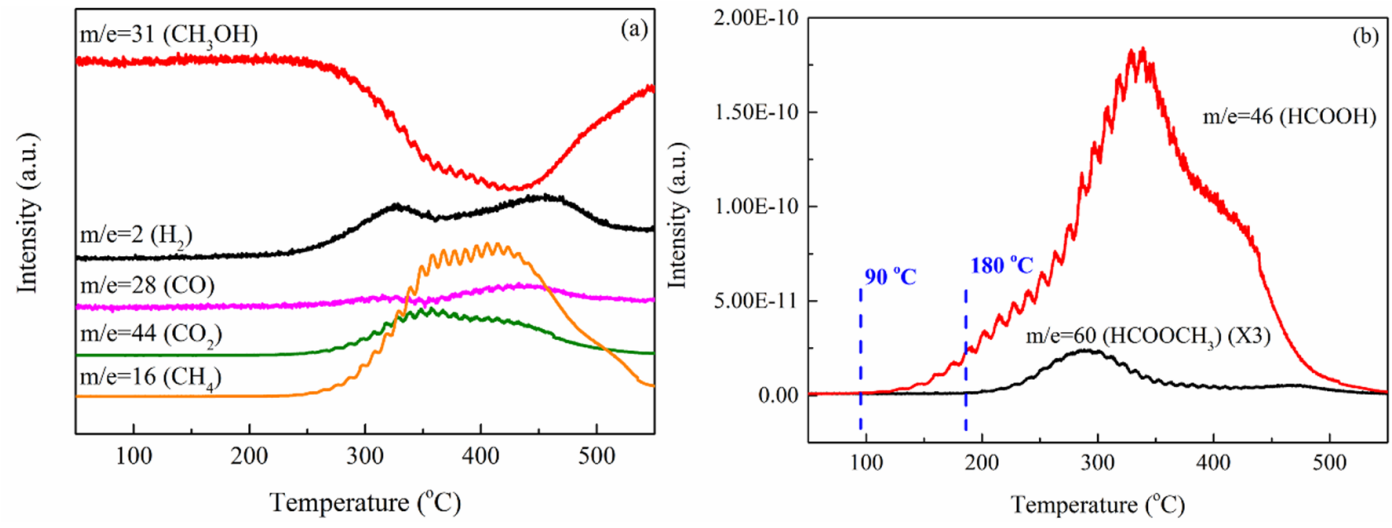
Fig.8
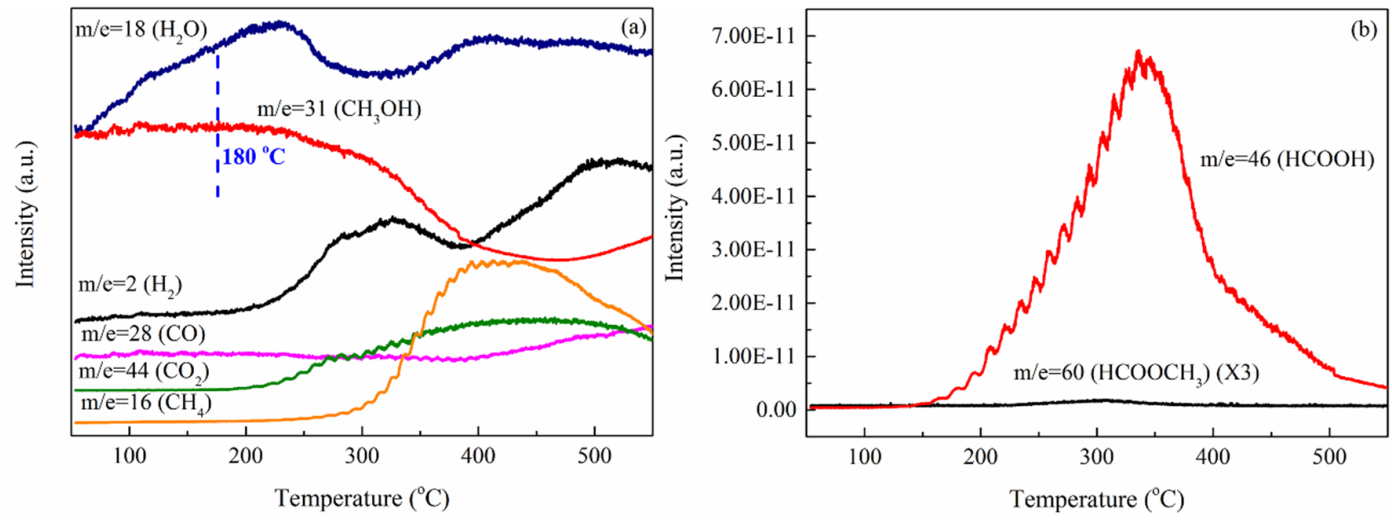
Fig.9
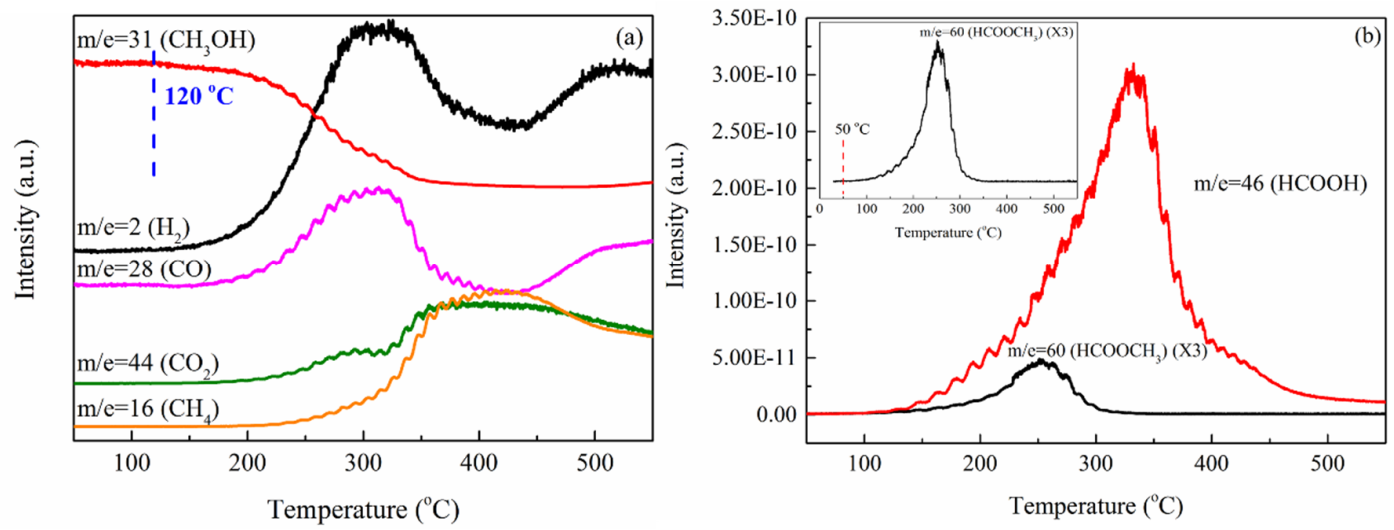
Fig.10
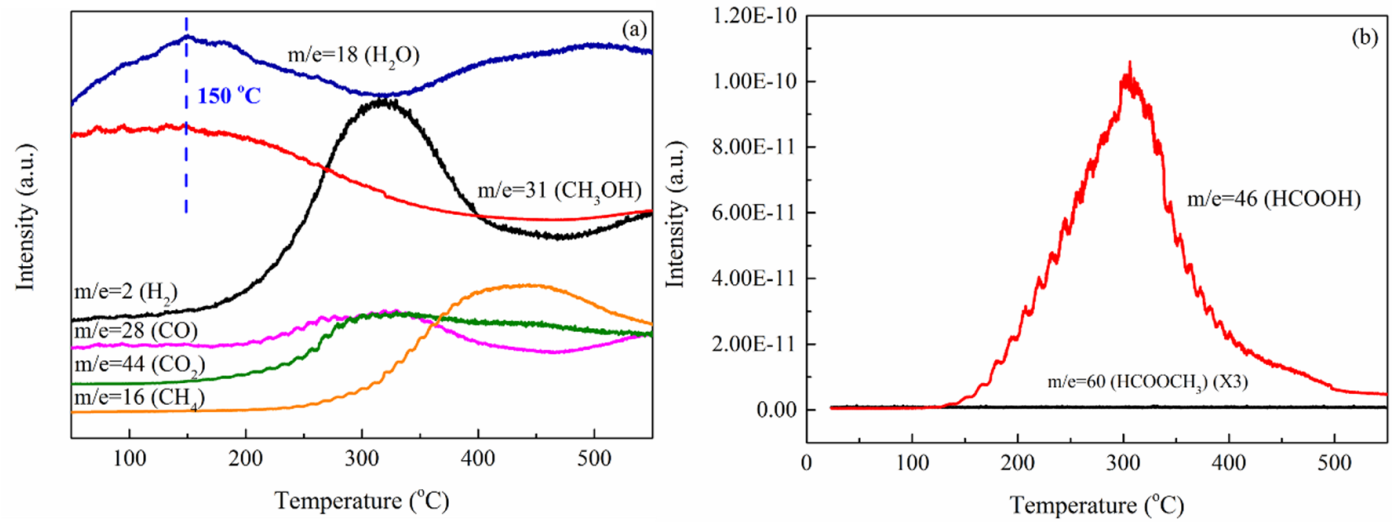
Fig.11

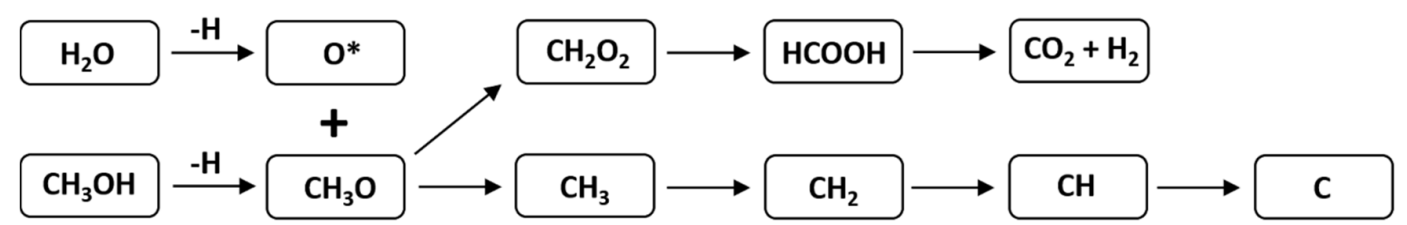


Fig.12

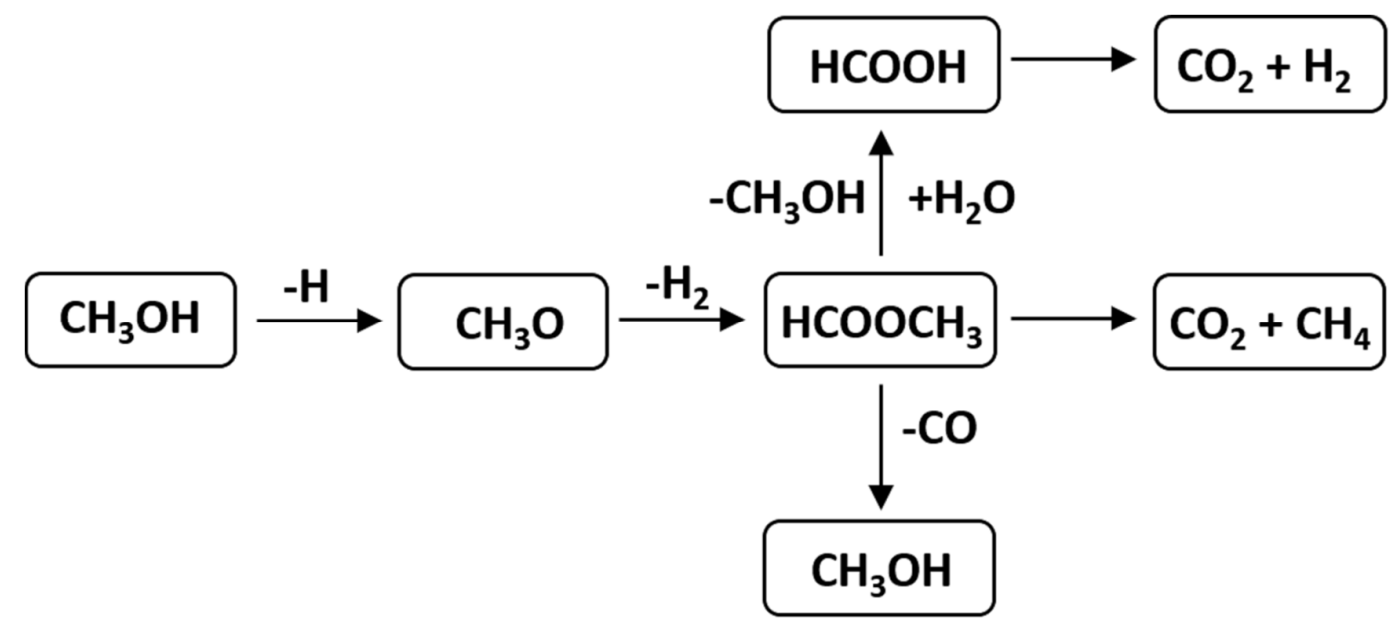


Graphical Abstract

$\mathrm{CH}_{3} \mathrm{OH}+\mathrm{H}_{2} \mathrm{O}$

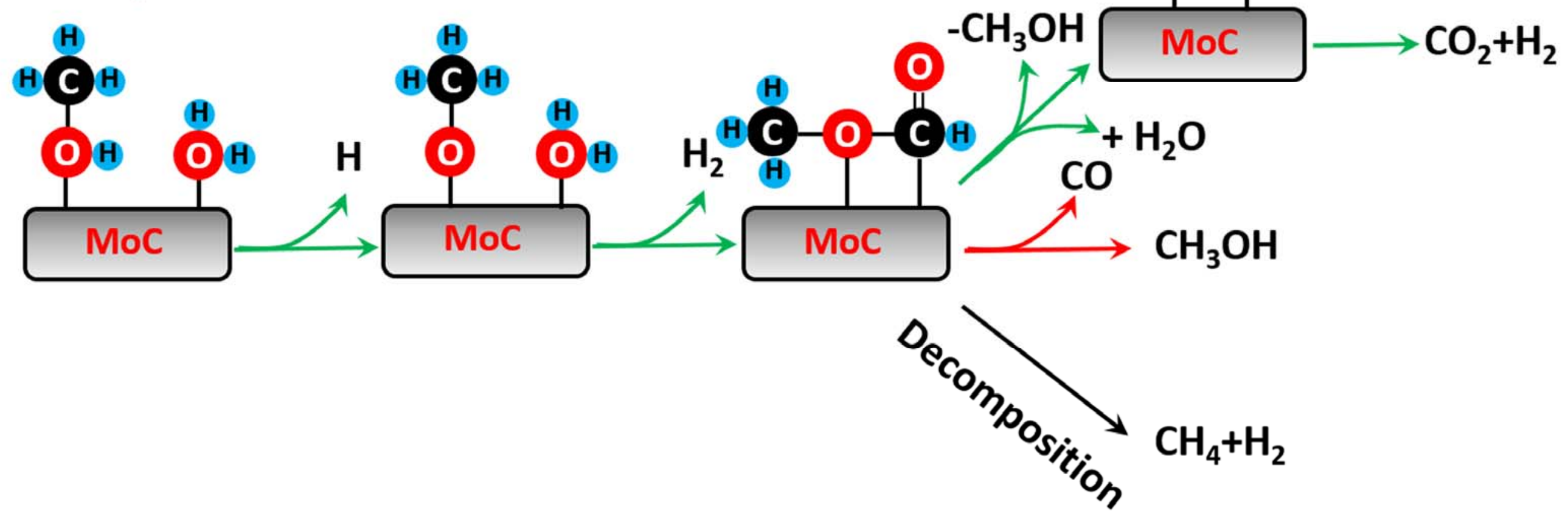

